\title{
An Assessment on the Physiochemical and Microbiological Parameters in Selected Sachet Water Sold for Consumption in Old Road Gaye Town Community Montserrado, County
}

\author{
Franklin Gonpue
}

\begin{abstract}
The study assessed the physicochemical and microbiological parameters in five selected sachet water brands that are sold for consumption in the Gaye Town Old Zoo community. The study is significant because the quality of drinking water plays a vital role in the health aspect of all human beings. An experimental design was employed to achieve the goal of the research. The population of the research was 150 and the sample size was 75 . The key findings of the research are: The Copper contents in the samples of the five selected brands of sachet water were above the stipulated WHO, (2012) water quality standards for drinking water. The concentrations of Cadmium, Chloride, Iron, Fluoride, pH, Turbidity and Total Hardness in the samples of the five different brands of sachet water met the stipulated standards for drinking water. The concentrations of Nitrite contents in three of the five brands met the stipulated standards for drinking water and the remaining two brands' concentrations of Nitrite contents were above the stipulated standards. The concentrations of Lead contents in one of the five brands were above the stipulated standards for drinking water. There were no bacteria present in three of the five sachet water brands. However, the presence of E.coli and Fecal Coliform was detected in the remaining two brands of sachet water. To conclude, none of the sachet water brands in the study area met all the parameters of the water quality standards for drinking water for both the Physiochemical and Microbiological parameters in relation to the World Health Organization (2012) drinking water quality standards and the Liberia Water Quality Standards (1987). It is recommended that; sachet water producers should have their water tested regularly especially in areas where fertilizers are commonly used where latrines (pit holes) are prevalent.
\end{abstract}

\section{INTRODUCTION}

\subsection{Background of the study}

afe drinking water is a basic need for human development, Wealth, and well-being and because of this; it is an internationally accepted human right (WHO, 2001). According to Udumu (2014), about $65 \%$ of the human body is water and the body needs water in order to maintain homeostasis.

Sachet water contains $500 \mathrm{ml}$ of water in a clear plastic bag that is electrically heated and sealed at opposite ends. Water used for sachet water is mostly obtained from groundwater, springs, and potable pipe-borne water. Prior to packaging, the water goes through a number of treatment processes, mainly filtration, in an attempt to make it purer and safer for consumption (Stoler, 2012).

Consequently, the well-being of human being depends largely on the quality of water they consume. An average man of $(53 \mathrm{~kg}-63 \mathrm{~kg})$ body weight requires about 3litres of water in liquid and food daily to keep healthy (Wardlow, 2004). This fact apparently accounts for why water is regarded as one of the most indispensable substances in life and like air it is most abundant. The unavailability of safe drinking water is widely spread and this has serious health implications. In developing nations of the world, $80 \%$ of all diseases and over $30 \%$ of deaths are related to drinking water (Ntukekpo, 1997). United Nations estimated that about 1.3 billion people all over the world lack access to potable water (Ajewole, 2005). The water of good drinking quality is of basic importance to human physiology, and man's continued existence depends very much on its availability (Nwosu and Ogueke, 2004). Several infectious diseases have been found to be transmitted through water (Mendez et al., 2004; Wright et al., 2004; Younes and Bartram, 2001) and some of these diseases are the most common causes of death in developing countries (Eshcol et al., 2009; WHO, 2004). It is therefore important that safe drinking water is provided especially in the rural and impoverished areas that depend on non-public water supply systems (Eshcol et al., 2009; Edema et al., 2001).

Water is said to be potable when its physical, chemical, and microbiological qualities conform to a specified standard. To achieve such a standard, raw water is subjected to purification processes that range from simple long-term storage to enable sedimentation of some suspended solids to aeration, coagulation, flocculation, filtration, and disinfection among other treatments (Ajewole, 2005). Water plays a major biochemical role in living things. It provides a medium for the transportation, assimilation, and utilization of important nutrients in human beings. This implies that if the water is polluted, biochemical processes in the body may be hindered (Anduang O. Odiongenyi, 2014).

Contaminated water still threatens the wellbeing of the population, particularly in under-developed and developing countries. Water quality and quantity are inextricably linked, 
but quality deserves special attention because of its implication on health and life (IJAET, 2014).

Safe drinking water contains microbial chemicals and physical characteristics that meet the WHO guidelines for national standards such as that of Ghana and Nigeria, on drinking water quality. Some of the guidelines are proposed by WHO (2012) are color (15 true color units, TCU), $\mathrm{pH}$ (6.5-8.5), Temperature $\left(25^{\circ} \mathrm{c}\right)$, Total dissolved solids, TDS $(600 \mathrm{mg} / \mathrm{l})$, Conductivity $(1000 \mu \mathrm{s} / \mathrm{cm})$. Several chemical constituents may dissolve in water and often tend to affect the physical properties of water; these chemical constituents should not be beyond the permissible limits. Since some of these constituents are toxic, the excess amounts in drinking water may cause health problems. For example, excess fluoride may create fluorosis, bleaching of the teeth, which is almost incurable. Lowry \& Fienen, (2013) examine that Arsenic, in an undesirable amount, may create a lot of health problems and make life miserable with incurable diseases. These contaminants in drinking water could endanger the lives of the consumer rather than improve them. Safe drinking water is essential to life and a satisfactory safe supply must be made available to consumers (M. Ackah et al, 2012). The use of water for drinking purposes is perhaps the most essential usage that should be given adequate attention because this may directly affect the health and well-being of human beings. Reported cases of different types of sickness associated with the consumption of polluted water have been documented to include cholera, diarrhea, hepatitis, dysentery, etc (Anduang O. Odiongenyi, 2015). Therefore, the need to analyze human drinking water cannot be overemphasized. According to the world health organization (WHO, 2014), the quality of drinking water is a powerful environmental determinant of health. The problem is even more pronounced in countries like Liberia with poor regulation of the sachet industry. The quality of water can be assessed by examining its physicochemical parameters, organoleptic properties, gross organic parameters, radionuclides, heavy metals, and bacteriological parameters (Eddy, 2004).

Therefore, this research will intend to answer the research question and give justifiable results about the quality of sachet water sold in the Gaye Town Old Zoo community.

\subsection{Statement of the problem}

There have been countless disease outbreaks and poisoning around the world resulting from the consumption of untreated or poorly treated drinking water (Fong, 2007). The sale and consumption of packaged water continue to grow rapidly in most countries of the world (Gardner, 2004). In the world, about 1.1 billion people do not have access to improved water supply while 2.4 billion do not have access to improved sanitation facilities. In addition, over 2 million people, mostly children less than 5 years of age mainly from developing countries with poor implementation of sustainable water programs, die every year of diarrhoeal diseases (WHO, 2011). Therefore, in order to accelerate development while enhancing environmental sustainability, it is opined that the proportion of people without access to sustainable safe drinking water and basic sanitation in the world should be reduced to half by the year 2015 (Teshamulwa, 2007). The increased demand for these drinking water products is attributed largely to factors such as inadequate or nonavailability of reliable, safe municipal water in urban areas; impression that high-quality natural spring water and potable drinking water offer a healthy, refreshing and great tasting alternative to high-calorie soft drinks; and convenience which has made the products meet the requirements of any lifestyle when needed (Gardner, 2004). Part of the problem of safe and potable water is the presence of heavy metals in the water. Depending on the nature of the soil and rock in the area and also largely on the amount of sewage sludge, industrial wastes (from refuse dump sites), fertilizers, and impurities, which may contain heavy metals like cadmium $(\mathrm{Cd})$, lead $(\mathrm{Pb})$, chromium $(\mathrm{Cr})$, nickel (Ni), silver (Ag), etc. that eventually percolates into the groundwater (Oluyemi et al.,2008) result to water pollution. It is against this backdrop that the study was undertaken to compare the physio-chemical and microbial parameters of selected sachet water brands that are sold in the Gaye Town, Old Zoo community with WHO and other accepted national standards.

\subsection{Research Questions}

The research answers the following questions:

1. What are the concentrations of the physic-chemical parameters of the various brands of sachet water being sold in the study area?

2. What are the microorganisms that are found in the various brands of the sachet waters that are under study?

3. What are the difference(s) in the physic-chemical and microbiological parameters of the five brands of sachet water that are being processed?

\subsection{Delimitations}

This research covers five different brands (most popular brands) of sachet water sold for consumption in the Gaye Town Community Sinkor Old Road namely: Prosperity Natural Mineral Water (PMW), Royalty Aqua Mineral Water (RAMW), Gentle Mineral Water (GMW), E\&F Mineral Water (E\&FMW), and Best Aqua Mineral Water (BAMW). Gaye Town Community is one of the most populated communities in Old Road and a residential environment.

\subsection{Limitations}

The researcher had limitation when it comes to access to advanced laboratory apparatus such as High-Power Liquid Chromatography (HPLC) amongst others for elemental analysis which lead to delay in getting many results within a short period of time and also access to the facilities where the 
sachet waters are being processed was difficult to assess and thus posed restriction in getting scientific information.

\subsection{Significance of the study}

Assurance of drinking safe water is a foundation for the prevention and control of water-borne diseases. The quality of drinking water plays a vital role in the health aspect of all human beings. Both groundwater and surface water resources are faced with unprecedented levels of pollutants everywhere. Therefore, periodic analysis of water meant for consumption is a must. The analysis of Water (especially Sachet Water) is a must and hence will enhance the following: Establish the potential health risks for the consuming populace of the study area; Provide policymakers with ample evidence to write policies that require Sachet water companies to have trained professionals such as chemists and microbiologists in their production line; Provides the Ministry of Health and other relevant bodies such as the Environmental Protection Agency (EPA), Liberia Water and Sewer Corporation (LWSC), National Standards Laboratory, National Public Health Institute of Liberia, etc. with information that increases the need for them to monitor the working conditions of sachet water companies and primordially, details of this research study will contain a reservoir of information in aiding other researchers and scientists not limited to graduate students in carrying out a research study of similar nature.

\subsection{Definitions of key terms}

Below are definitions of key terms that are in the research:

Cholera: An acute infection of the small intestine caused by the bacterium Vibrio cholera and characterized by extreme diarrhea with rapid and severe depletion of body fluids and salts.

Electrical Conductivity: a measure of the material's ability to conduct electricity.

Polyethylene: is a major group of thermoplastic polymers, produced by the polymerization of ethylene.

\subsection{Organization of the study}

The research is divided into five chapters. The first chapter comprises the background of the study, statement of the problem, the significance of the study, research question, research objective, limitation and delimitation of the study, definition of key terms and organization of the study. The second chapter gives detail of the findings of other researchers and scientists which provide information relevant to this research study as such is a function of Literature and review. The third chapter reflects on the research methodology, which includes the research setting, research design, and research population, data collection instruments, sample collection and sampling technique, data collection procedures, and data analysis procedures. The fourth chapter specifically deals with the presentation and analysis of data. Finally, the fifth chapter presents the summary, conclusion recommendations.

\section{REVIEW OF RELATED LITERATURE}

\subsection{Water quality}

The quality of water is usually described by its physical, chemical, and biological characteristics (Navendu Sharma, 2017).

Water quality is a term used here to express the suitability of water to sustain various uses or processes. Any particular user will have certain requirements for the physical, chemical microbial characteristics of water, for example, limits on the concentration of toxic substances for drinking water use, or restrictions on temperature, conductivity, and $\mathrm{pH}$ ranges for sachet water.

Consequently, water quality can be defined by a range of variables that limit water use (UNEP, 1996). Water quality is thought of as the measure of suitability for a particular use based on physical and chemical characteristics. Water quality is affected by a wide range of natural and human influences. The most important of the natural influences are geological, hydrological, and climatic since these affect the quantity and quality of water available. Their influence is generally greatest when available water quantities are low and maximum use must be made of the limited resource; for example, high salinity is a frequent problem in arid and coastal areas (WHO, 2010).

The term related public health hazards refer to the physical, chemical, and biological properties that affect drinking water fitness for public use (Hoekstra, 2006). Parameters for water quality are determined when considering water use in order to alert consumers' attention about their effect on waters and how they too contribute to its quality.

According to the WHO Guidelines, water for drinking must not be present any significant risk to the health of the consumer over a lifetime of consumption (WHO, 2011). Neither should the consumption of such water present sensitivities that may arise between life stages. Invariability, safe drinking water should be colorless and tasteless, free from harmful chemicals as well as other suspended materials, and most importantly should be devoid of disease-causing organisms (Izah, 2015). Among many other concerns, the possibility of drinking water being the source of diseasecausing organisms and related illnesses has been a huge hurdle to overcome, especially in parts of developing countries where availability, accessibility, and affordability of portable and safe drinking water continue to be a challenge (Stoler, 2012).

\subsection{Ground water}

Groundwater is held in the pore space of sediments such as sands or gravels or in the fissures of fractured rock such as crystalline rock and limestone. The body of rock or sediments containing the water is termed as an aquifer and the upper water level in the saturated body is termed as the water table. Typically, ground water has a steady flow pattern. The quality 
of ground water depends on the composition of the recharge water, the interaction between the water and soil, soil gas and rocks with which it comes into contact in the unsaturated zone, and the residence time and reactions that take place within the aquifer (UNEP, 1996)

\subsection{Water pollution}

Good quality water is odorless, colorless, practically tasteless, and free from fecal pollution (Ezeugwunne et al., 2009).

Environmentally, water is so important that its pollution becomes a serious problem since it affects the lives of many people throughout the world. Pollutants in natural waters could be microbial or chemical in origin. The chemical pollutants are the organic and inorganic substances whose levels continue to rise due to increased discharge of chemical fertilizers, particles, and pesticides from agricultural activities. The microbial pollutants, on the other hand, include coliform bacteria which are indicator organisms mostly used in bacterial water characterization. They are easily found in animal feces, soils, and raw surface waters (Ezeugwunne et al., 2009). Polluted water harms human, animal, and plant lives resulting in high mortality rates especially if their sulfate-bicarbonate ratios are high causing cerebral hemorrhage, cardiovascular, and other chronic diseases (WHO, 2004a; Kwakye-Nuako et al., 2007; WHO, 2008).

Water is a unique substance because it can naturally be renewed and cleansed, by allowing pollutants to settle out (through the process of sedimentation) or break down, or by diluting the pollutant to a point where they are not harmful concentration. However, this natural process takes time and is difficult when excessive quantities of harmful contaminants are added to the water (SDWF, 2012). Groundwater quality is influenced by the effects of human activities which caused pollution at the land surface because most groundwater originates by recharge of rainwater infiltrating from the surface. The rainwater itself may also have increased acidity due to human activity (UNEP, 1996). Most types of pollution and pollutants encountered in domestic and industrial wastewaters are fertilizers, heavy metals, sulfates, nitrates, chlorides, phosphates, carbonates, ammonia, pesticides, phenols, soaps, detergents are chemical pollutants that usually contaminate water bodies (Margolis, 2012). In Thailand, the Ministry of Public Health reported the results of pollution monitoring of 32 rivers, as shown in table 2.1.3.

\subsection{Public Health Implications of Microbial pollution of commercially sold sachet/ packaged water}

Water has always been associated with the disease. The first reported case of polluted drinking water was that of Broad street water pump, London after which many other cases have been reported in different parts of the world (Gangil et al., 2013). Conditions resulting from microbial contamination of drinking water are said to affect a large part of the world's population (Hughes and Koplan, 2005) and continue to be one of the major health problems globally (Boubetra et al., 2011). It accounts for $80 \%$ of illnesses in the developing world
(Isirimah, 2003). Microbial pollution of packaged water particularly in developing countries has grave implications on public health (Warren and Mark, 1998). It threatens the population's existence causing diseases such as cholera (Njoku and Osondu, 2007; Ackah-Arthur et al., 2012), gastroenteritis (Grabow, 1996), hepatitis, typhoid fever, shigellosis (Oguntoyinbo et al., 1978; Gangarose et al., 1980; Fraechem et al., 1983; Jiburum and Mba, 2004; Kwakye et al., 2007; Banu and Menakuru, 2010; Anyamene and Ojiagu, 2014) and giardiasis (Opara and Nnadim, 2014). It could also result in symptoms such as bacillary diarrhea (Mead et al., 1999). WHO estimates that $88 \%$ of diarrhea cases are caused by unsafe water (CAWST, 2009; WHO, 2004). Mortalities due to water-associated diseases and symptoms now exceed 5 million people per year (Cabral, 2010). Studies carried out on packaged water around the world revealed high levels of contamination of microorganisms which indicated that most of the brands were unfit for human consumption. They were found to be of doubtful quality and did not meet the WHO drinking water standards (Rutz, 1996). Consumption of these packaged water brands could result in public health hazards. This, therefore, requires a concerted effort on the part of all stakeholders to correct the anomaly.

\subsection{Physical Parameters}

The physical parameters of water quality include color, odor, taste, $\mathrm{pH}$, temperature, Total dissolved solids (TDS), and Electric Conductivity.

Color: There is ideally no visible color for drinking water: Drinking watercolor is primarily due to the presence of colored organic matter (primarily humic and fulvic acids) associated with the humus fraction of soil. Color is also influenced by corrosion in water or the presence of Magnesium, Iron, and other metals. Color in water is also the first indication of a hazardous situation characterized by the contamination of water with industrial effluents. The levels of color below 15TCU (True Color Unit) are acceptable for transient consumers. The true color is the color that remains after any suspended particles have been removed from the water. According to WHO, there is no health-based guideline value proposed for color in drinking water. (WHO, 2012).

Electrical conductivity: Conductivity is the ability of any medium; water in this case, to conduct an electric current. The presence of dissolved solids such as Magnesium, Calcium, and Chloride, in water samples, carries the electric current through water. The standard for drinking water quality according to the World Health Organization is $1,000 \mu \mathrm{Sm} / \mathrm{cm}$. (WHO, 2012). The conductivity is a numerical expression of water's ability to conduct electric current and depends on the concentration of ions in solution; conductivity measurement is an excellent indicator of TDS, which is a measure of salinity that affects the taste of potable water (Yogesh Kumar WalIa, 2017). 
The potential hydrogen $(\mathrm{pH})$ : The $\mathrm{pH}$ is a measure of the acidity, basicity, and neutrality of a particular solution. The range goes from $0-14$, with 7 being neutral. the $\mathrm{pH}$ of less than 7 indicates acidity, whereas a $\mathrm{pH}$ of greater than 7 indicates a base. $\mathrm{pH}$ is really a measure of the relative amount of free hydrogen and hydroxyl ions in the water. Water that has more free hydrogen ions is acidic, whereas water that has more free hydroxyl ions is basic. Since $\mathrm{pH}$ can be affected by chemicals in the water, $\mathrm{pH}$ is an important indicator of water that is changing chemically. $\mathrm{pH}$ is reported in "logarithmic units". Each number represents a 10-fold change in the acidity/alkalinity of the water. Water with a $\mathrm{pH}$ of five is ten times more acidic than water having a $\mathrm{pH}$ of six. $\mathrm{pH}$ refers to the amount of hydrogen found in a substance (in this case, water). The $\mathrm{pH}$ of water determines the solubility (the amount that can be dissolved in the water) and biological availability (the amount that can be utilized by aquatic life) of chemical constituents such as nutrients (phosphorus, nitrogen, and carbon) and heavy metals (lead, copper, cadmium, etc.). For example, in addition to affecting how much and what form of phosphorus is most abundant in the water, $\mathrm{pH}$ also determines whether aquatic life can use it. In the case of heavy metals, the degree to which they are soluble determines their toxicity. Metals tend to be more toxic at lower $\mathrm{pH}$ because they are more soluble. Low water $\mathrm{pH}$ can cause gastrointestinal irritation in sensitive individuals. The standard of water quality on $\mathrm{pH}$ level above 8.5 indicates that a high level of base or alkalinity substance is present in water. An increase in the base does not pose a health risk but can cause aesthetic problems, such as an alkali taste to the water that makes coffee taste bitter Udumu, (2014). According to Ahimah \& Ofuso, samples of sachet water with $\mathrm{pH}$ values of 6.40 to 7.30 are considered fit for consumption in line with the Ghanaian and WHO guidelines on drinking water quality. (Ahimah \& Ofuso, 2012).

Temperature: The temperature is one of the most important parameters in water. It affects sediments, microbial growth, color, taste, and corrosion. Water at low temperature (cold water) is palatable than water at higher temperature (warm water). The maximum permitted standard of drinking water is $25^{\circ} \mathrm{C}$. (WHO, 2012). According to Ahimah \& Ofosu, the temperatures of some analyzed samples of sachet water were between 24.6 and $26.6^{\circ} \mathrm{C}$ and therefore these samples were considered fit for consumption. (Ahimah \& Ofosu, 2012).

\subsection{Chemical parameters:}

The chemical parameters of water include the following: chlorides, Iron, Turbidity, Total hardness, Lead, Copper, Cadmium, Nitrite, and Fluoride.

Chloride: The concentrations of chloride in excess of 250 $\mathrm{mg} / \mathrm{L}$ may alter a salty taste to the water. The taste threshold of chloride anion becomes increasingly noticeable at a maximum of $250 \mathrm{mg} / \mathrm{L}$. It must however be noted that the salty taste of water is variable and as such depends on the chemical composition of the water. No study has shown that the ingestion of chloride content poses a serious health risk to humans and as such, there is no health-based guideline value. (WHO, 2012). Chloride, in the form of sodium $(\mathrm{NaCl})$, potassium $(\mathrm{KCl})$, or calcium $(\mathrm{CaCl} 2)$ is one of the major inorganic anions in fresh and waste-water but in potable water, the salty taste produced by it varies and depends upon the chemical composition of the water. While some waters containing $250 \mathrm{mg}$ chloride in a liter may have a detectable salty taste if the cation is 'sodium, others may not have if their dominant cations are calcium and magnesium. High chloride content may harm metallic pipes and structures as well as growing plants, cause hypertension, and increase the concentration of other metals in water (WHO, 2003).

Iron: The iron content of water is of considerable concern because small amounts seriously affect its usefulness. It causes staining of plumbing fixtures; staining of clothes and plugging of pipes. Iron-bearing waters also favor the growth of iron bacteria, such as crenothrix. Iron in water sufficiently indicates the presence of E-Coliforms which is an indication of sewage contamination and can cause dysentery, typhoid, etc. (WHO, 2011).

Total Hardness: Total Hardness Total hardness of the water expresses the role of dissolved minerals especially in terms of Calcium and Magnesium which determines the suitability of water for various purposes such as domestic, industrial, drinking, etc. and applied to the presence of bicarbonates, sulfates, chlorides and nitrates of both calcium and Magnesium (Navendu Sharma1 \& Yogesh Kumar WalIa, 2017). Total hardness of the water expresses the role of dissolved minerals especially in terms of Calcium and Magnesium which determines the suitability of water for various purposes such as domestic, industrial, drinking, etc. and applied to the presence of bicarbonates, sulphates, chlorides and nitrates of both calcium and Magnesium (Taylor, 1994).

Turbidity: Turbidity is the cloudiness of water caused by a variety of suspended particles or colloidal matter that obstructs the propagation or transmission of light through the water. Turbidity is the measure of the relative clarity of a liquid. It is an optical characteristic of water and is an expression of the amount of light that is scattered by material in the water when a light is shined through the water sample. The higher the intensity of the scattered light, the higher the turbidity. Material that causes water to be turbid includes clay, silt, finely divided inorganic and organic matter, algae, soluble colored organic compounds, and plankton, and other microscopic organisms. Turbidity makes the water cloudy or opaque. Excessive turbidity, or cloudiness, in drinking water is aesthetically unappealing, and may also represent a health concern. Turbidity can provide food and shelter for pathogens. If not removed, turbidity can promote the regrowth of pathogens in the distribution system, leading to waterborne disease outbreaks, which have caused significant cases of gastroenteritis throughout the United States and the world. The particles of turbidity provide "shelter" for microbes by reducing their exposure to attack by disinfectants. Fortunately, 
traditional water treatment processes have the ability to effectively remove turbidity when operated properly.

Turbidity in surface waters may be the consequence of particulate matter of many types and is likely to include attached microorganisms that are a threat to health. The turbidity range set by WHO is 5 Nephelometric Turbidity Unit (NTU). (WHO, 2012).

Turbidity for the water is an important property, which affects light penetration. Turbidity is the measure of suspended sediment such as silt, clay, organic matter, and microscopic organisms in a water samples (Navendu Sharma, 2017).

Nitrite: Nitrites are relatively short-lived because they are quickly converted to nitrates by bacteria. Nitrites produce a serious illness (blood disease) in fish. They also react directly with hemoglobin in human blood to produce methemoglobin, which destroys the ability of blood cells to transport oxygen. This condition is especially serious in babies less than three months of age as it causes a condition known as methemoglobinemia or blue baby disease. Water with nitrite levels exceeding $1.0 \mathrm{mg} / \mathrm{l}$ should not be given to babies. (Martins Okechukwu Isikwu \& Ada Okey Chikezie, 2014).

Fluoride: Fluoride inhibits enzymes that breed acidproducing bacteria whose acid eats away tooth enamel. Excessive fluoride intake leads to loss of calcium from the tooth matrix, aggravating cavity formation throughout life rather than remedying it and so causing dental fluorosis. Severe, chronic, and cumulative overexposure can cause the incurable crippling of skeletal fluorosis. The probable source might be during weathering and circulation of water in rocks and soil, fluorine is leached out and dissolved in water. (Martins Okechukwu Isikwu \& Ada Okey Chikezie, 2014).

Calcium: Calcium is mainly the micronutrient that is present in an aquatic environment. The hardness of water is of chief significance in connection with the discharge of sewage and industrial pollutants, as shown by variations in the concentration of the hardness of the water. Calcium causes both carbonate and non-carbonate hardness of the water. The concentration of calcium in river water may be due to the occurrence of highly soluble halides, gypsum, and easily weathered surface rocks. (Navendu sharma1 \& Yogesh Kumar Walla, 2017). Calcium is mainly the micronutrient that presents in an aquatic environment. The hardness of the river water is of chief significance in connection with the discharge of sewage and industrial pollutants, as shown by variations in the concentration of the hardness of the water. Calcium causes both carbonate and non-carbonate hardness of water (Sharm, 2015).

Lead: It has been shown in some studies that the effects of early childhood exposure to lead to neurodevelopment persist into the second decade of life (Ris et al., 2004). Some adverse health conditions have been linked to prenatal lead exposure to mother and infant. These include fertility problems, hypertension, and infant neurodevelopment (Bellinger, 2005). Prolonged drinking of such waters by children and expectant mothers could result in certain ailments which include IQ loss (Tellez-Rojo et al., 2006; Lanphear et al., 2005; Canfield et al., 2003). As more lead is consumed in lead-contaminated water the greater the risk of having lead-associated ailments.

Zinc: Zinc is an essential element needed by the body and is commonly found in nutritional supplements and all foods. However, when taken in a relatively large quantity over a period of time, zinc affects human health (PBC, 1998). Although drinking water usually makes a negligible contribution to zinc intake, corrosion of pipes and fittings can make contributions from tap water to be up to $10 \%$ of the daily intake (WHO, 2003a; ATSDR, 2011). The zinc contents of the samples ranged from $0.28 \pm 0.01$ (Happy Days) to 2.41 $\pm 0.10 \mathrm{mgdm}-3$ (Evershine) and these were below the maximum 3.0 mgdm-3 value given by EPA and WHO for this metal in potable waters. Thus, these samples were not expected to have any undesirable astringent taste or form opalescent and greasy film especially when boiled (WHO, 2003a).

Chromium: Chromium exists in oxidation states of +2 to +6 but is almost always in the trivalent state when in solution or most of its salts. The distribution of its compounds in the +3 and +6 states depends on the redox potential, $\mathrm{pH}$, presence of oxidizing or reducing agents, the kinetics of the redox reactions, formation of chromium (III) complexes, or insoluble chromium (III) salts, and the total chromium concentration. In water, chromium (III) which is adsorbed at relatively high $\mathrm{pH}$ values exists as the hydroxides and complexes although its concentration depends on the type of water (WHO, 2003a). The chromium contents of the water samples in this study were from $0.01 \pm 0.00$ to $0.04 \pm 0.01$ $\mathrm{mg} / \mathrm{dm} 3$ (Supreme water) although this metal was not detected in three water samples (Zagbayi, FUTMin, and Sabo Best waters). These levels were also below the highest limit set by either WHO or EPA (2011d).

Copper: Copper is a transition metal that is stable in its metallic state and forms monovalent $(\mathrm{Cu}+)$ and divalent $(\mathrm{Cu} 2+)$ ions. It is an essential nutrient, required by the body in minute quantities. Dissolved copper sometimes imparts a light blue or blue-green color and an unpleasant metallic, bitter taste to drinking water (ATSDR, 2002). It is a potential health hazard that causes various health problems when people are exposed to it at levels above the permissible value. Short periods of exposure can cause gastrointestinal disturbance, including nausea and vomiting while the use of water whose copper level exceeds the maximum value over many years causes liver or kidney damage (EPA, 2011b; WHO, 2004b).

Nitrates: Nitrates are readily converted to nitrites and vice versa and are present naturally in soils, water, and foods. They get into water through chemical fertilizers, soil, foods, glass, and explosives (ANL, 2005; WHO, 2007). These compounds are very soluble in water and can enter surface water when it rains or groundwater through leaching. Nitrate is a normal component of the human diet and it is relatively nontoxic but when swallowed, it is converted to nitrite which reacts with 
hemoglobin in the blood causing methemoglobin that could result in coma and death especially in infants. It also causes diuresis and hemorrhage of the spleen. Excess of it in water is used as an indicator of poor water quality (ANL, 2005). The major sources of nitrite in drinking water are runoff from fertilizer use, leaching from septic tanks, sewage, and erosion of natural deposits (Cam et al., 2008).

\subsection{Microbiological Parameters}

The Microbiological parameters include fecal coliform, coliform, and E-coli bacterial.

In a study to investigate the bacteriological quality of sachet water produced and sold in Teshie-Nungua, a suburb known for perennial water shortages, Addo et al. (2009) reported a sachet water samples with suspicious microbial contamination based on the most portable number (MPN) values. Fecal coliforms were detected in several samples while some of the samples were also contaminated with Escherichia coli. Given the vast number of people that rely on sachet water for their drinking needs, it is imperative that its quality is of the highest standard to avert any future waterborne outbreaks related to its consumption.

The quality of packaged assessed in Nigeria showed some levels of microbial contamination (Izah, 2015). The results of the study indicated that bottled water has a lower microbial load than sachet water. E. coli, Clostridium perfringens spore, and fecal Streptococcus were the most common isolated microbe from the packaged water. A similar study on the quality of portable water in Benin showed that some of the drinking water tested had microbiological pollution exceeding the approved levels, hence making the drinking water not wholesome for consumption (Johnson, 2016). Although packaged water is an improved source of drinking water, it is not totally free from microbial contaminations; hence the need for enhanced monitoring strategies to ensure that packaged water is always safe for human consumption (Bain, 2014).

Fecal coliforms are the indicator organisms. They indicate the presence of other pathogenic bacteria (Ombaka, 2012). Diseases and illnesses that can be contracted in water with high fecal coliform counts include; typhoid fever, hepatitis, gastroenteritis, dysentery, and ear infections. This is clearly evident in the value of tap water. Ideally, drinking water should not contain any microorganisms. Factors affecting fecal coliform include wastewater and septic system effluent, animal waste, sediment load, temperature, and nutrients. In guidelines for the bacterial water quality, consideration should be given not only to the source of drinking water but also to the treatment, method of delivering to the consumer, and frequency of examination ((Isikwue, M.O., Iorver, D. \& Onoja, S.B. (2011).

The presence of coliforms in all samples and E. coli in some of the samples is an indication of the poor sanitary levels maintained by the producers, and it could be that the source of water has been contaminated with human or animal feces since E. coli is a normal flora organism in man and animals
(Trevett et al., 2005). The incidence of E. coli in boreholes is, therefore, a concern as such sources are usually regarded as "safe" (Taulo et al., 2008).

The presence of coliform (either total or fecal) may be an indication of poor treatment or contact with surface water sources. The extent of pollution was discovered to vary with the depth of water source and season (Isikwue, M.O., Iorver, D. \& Onoja, S.B. (2011). This can, however, be treated by chlorination. Adequate waste management is a key factor in the preservation of water quality. Poor and improper waste management systems have constituted a menace to groundwater aquifers. (Awajiogak, A.U, 2013). The presence of coliform in water is indicative of pollution. The presence of coliform in the present study may be due to the unhygienic environment of the boreholes and factories where the sachet water is packaged (Agwu, 2008).

\subsection{Sachet Water}

Access to safe drinking water is important to health and development (Adetunde et al., 2014), but because of its inadequacy and the government's inability to provide enough, a number of small-scale waters producing industries are packaging and marketing factory filled sachet drinking water (Thliza et al., 2015). These are small nylon sachets containing $0.5 \mathrm{~L}$ of water which are electrically heated and sealed at both ends (Adegoke et al., 2012). The sale and consumption of packaged water continue to grow astronomically and rapidly in most countries of the world (Mgbakor et al., 2011; Oyedeji et al., 2010; Gangil et al., 2013). The quest for the cheap and readily available source of potable water has led to the emergence of sachet water (Anyamene and Ojiagu, 2014) which is a locally sourced low-cost alternative drinking water scheme providing sustainable access to safe water in rural and semi-urban settings of developing nations (USEPA, 2012; Balogun et al., 2014). This is thought to be cheaper and more affordable than bottled water and also safer, more hygienic, and better than hand-filled, hand-tied packaged polythene bag water initially popularly sold (Oyedeji et al., 2010; Akinde et al., 2011). Consequently, sachet water has gradually become the most consumed liquid for both the rich and poor (Akinde et al., 2011). Current trends however unfortunately suggest that sachet water could be a route of transmission of enteric pathogens which raises issues of the problem of its purity and health concern (Oladapo et al., 2009; Mgbakor et al., 2011; Akinde et al., 2011; Isikwue and Chikezie, 2014).

\subsection{Packaged/Sachet Water Contamination}

Packaged water, no matter their sources, are susceptible to microbial, toxic organic and inorganic contamination (Anyamene and Ojiagu, 2014; Sudhakar and Manatha, 2004; Gangil et al., 2013). The presence of coliforms in potable water is used as indicator of water contamination (Opara and Nnodim, 2014). Coliform bacteria describe a group of enteric bacteria that include E. coli, Klebsiella and Enterobacter species. They are rod shaped, gram negative organisms which ferment lactose with the production of acid and gas when 
incubated at $37^{\circ} \mathrm{C}$ for 48 hours. They are broad class bacteria that live in the digestive tract of humans and animals (Opara and Nnodim 2014). Although coliforms are generally not harmful, they indicate the presence of pathogenic bacteria, viruses and protozoa (Anyamene and Ojiagu, 2014; Goel, 2006). Escherichia coli is used as indicator of possible recent sewage/ faecal contamination (Anyamene and Ojiagu, 2014; Onuh and Isaac, 2009; Opara and Nnodim, 2004) because this is one of the first bacteria present in water when contamination occurs and will present in larger quantities than some other pathogenic microbes. Other microbial indicators of possible faecal, soil and natural water contaminations are faecal Enterococci especially Enterobacter faecalis, Clostridium perfringens spores, Clostridium sporanges, Salmonella typhi, Shigella dysenteriae, Vibrio cholera, Pseudomonas aeruginosa, Klebsiella spp. Aeromonas spp., Mycobacterium spp., Alcaligens, Actinetobacter, Chromobacterium, Serratia spp, Flavobacterium spp., Proteus spp., Bacillus subtilis, B. mycoides, Enterobacter cloaca, Enterobacter aeronenes, Nostocida fexibacter and Norcardia spp. (WHO, 1993; Edema et al., 2001; Tortora et al., 2002; Oyedeji et al., 2010; Khaniki et al., 2010; Cleark, 2010; Oludairo et al., 2013; Onilude et al., 2013; Falegan et al., 2014). These could cause different disease conditions and clinical signs such as giardiasis, cryptosporidiosis, gastroenteritis, diarrhea, typhoid fever, cholera, bacillary dysentery, hepatitis, shigellosis etc. (Akinde et al., 2011; Thliza et al., 2015; Oyedeji et al., 2010; Isikwue and Chikezie, 2014; Aroh et al., 2013; Hughes and Koplan, 2005).

\section{RESEARCH METHODOLOGY}

\subsection{Research design}

An experimental research design was employed to achieve the goal of the research study of which the mechanism was largely dependent on both instrumental and classical analysis. Samples were collected from the processing sites and analyses were conducted to assess the Physiochemical and Microbiological parameters in the samples.

\subsection{Population}

The population of the study area (Gaye Town Community) is nine thousand one hundred and twenty-five $(9,125)$; it is the most populated community in Old Road (LIGIS 2014). This research constitutes five different brands of water sacks, each pack containing thirty (30) sachets yielding a total of one hundred and fifty sachets that defines the beneficial population, which are processed mineral waters in the abovementioned sample site locations from the different mineral water processing companies, namely: Prosperity Natural Mineral Water (PNMW), Royalty Aqua Mineral Water (RAMW), Gentle Mineral Water (GMW), E\&F Mineral Water (E\&FMW), and Best Aqua Mineral Water (BAMW).

\subsection{Sample size and Sampling Technique}

The sample size for the research is 75 . One sac which contains thirty (30) sachets was collected randomly from each sachet water company and 15 sachets of each of the five different brands with a total of seventy-five (sachets)/samples were used for the analysis.

Random sampling techniques were employed in the research study; specific brands of mineral water were selected indicative of the former, after which fifteen (15) sachets of each sack of the brands were randomly sampled out thus homogenized indicative of the latter and these were later assayed for analysis.

Each brand of water pack containing thirty sachets was bought directly from the processing stations or the mini-industry that processes the water. Each brand of water was wrapped well in a large doubled blue polyethylene bag and was clearly marked using marker for proper and easy identification.

At the various sites where the mineral waters are processed, ambient temperatures were observed and were done prior to wrapping the specific mineral sack in order to avoid excessive sunlight that would increase temperature leading to alterations in the components of the analyte under investigation. Also, before carrying the mineral sacks to National Standards Laboratory it was ensured that the sachet water was packed carefully to avoid excessive collisions leading to the bursting of the sachets in sacks understudy, in addition, the packs were prevented from piercing materials or objects.

The mineral water sacks were removed from the large double blue polyethylene bags that are meant to protect the mineral sacks from direct sunlight in order to maintain $\pm 25^{\circ} \mathrm{C}$ and each was packed in a clean, cool, and dried location in the laboratory for easier identification. Subsequently, in order to get an assay from the fifteen samples of each sack of mineral water representative of the population, sterilized scissors was used to cut each sachet that was placed in a sterilized vessel having the capacity to hold all seventy-five sachets each 500 $\mathrm{mL}$ before transferring the assay in a sterilized beaker set for both classical and instrumental analysis.

Each test was conducted three times as a replicate in order to have an average value.

\subsection{Data Collection Instruments}

Spectroquant Pharo 300 was used to conduct the chemical analysis: Lead, Copper Iron, Calcium, Fluoride, Chloride, Nitrite, and Total Hardness. Jenway $\mathrm{pH}$ meter, beaker, sterilized scissors were used to conduct the physical analysis: $\mathrm{pH}$, Temperature and the Mrc-TU 2016 was used to conduct the Turbidity analysis. An incubator, test tube, Colony counter, and microscope were used to conduct the microbiological analysis. The test report form was also used for data collection.

\subsection{Data Collection Procedures}

After the research have been accepted by the college of health sciences, the researcher obtains a letter from the Dean of the College of Health Sciences that was given to the management of each of the five brands where the sachet water is processed 
and produce in order to have access to the facilities and collect samples that were used to conduct the analysis. The samples were then taken to the National Standards of Liberia where the below procedures were used to collect the analytical data.

Hydrogen Ion Index (pH) and Temperature: After homogenizing the sample, $50 \mathrm{ml}$ of the sample assay was distributed in three beakers and the Jenway $\mathrm{pH}$ meter 300 was pulled in each beaker for $10 \mathrm{mins}$ for analysis.

Turbidity: $50 \mathrm{ml}$ of the homogenized sample was placed in the Mrc-TU2016 sample bottles to conduct the analysis.

Lead: $0.50 \mathrm{ml}$ of lead reagent $(\mathrm{Pb}-1)$ was placed in a test tube; $0.50 \mathrm{ml}$ of lead reagent $(\mathrm{Pb}-2)$ were added to the same test tube and mix; $8.0 \mathrm{ml}$ of the pretreated sample was added and after mixing; it was transferred into a $10 \mathrm{~mm}$ culvert which was well wept and then place it in the photometer (Spectroquant 300) for analysis.

Copper: $5.0 \mathrm{ml}$ of the pretreated sample was placed in a test tube using a pipette; one level green dosing spoon of copper reagent $(\mathrm{Cu}-1)$ was added and shaken vigorously until the reagent was completely dissolved; 5 drops of reagent $(\mathrm{Cu}-2)$ was added; after mixing, it had a reaction time of 5minutes before it was placed in a $10 \mathrm{~mm}$ culvert and then transfer to the photometer (Spectroquant 300) for analysis.

Calcium: $0.5-\mathrm{ml}$ of the pretreated sample was placed into a test tube; $5.0 \mathrm{ml}$ of Calcium reagent $(\mathrm{Ca}-1)$ was added and mixed; 4 drops of calcium reagent $(\mathrm{Ca}-2)$ was added and mixed; 4 drops of calcium reagent was also added (Ca-3) and mix which had a reaction time of exactly 8 minutes before it was placed into a $10 \mathrm{~mm}$ cell of the culvert and then transfer in the photometer (Spectroquant 300) for analysis.

Fluoride: $2.0 \mathrm{ml}$ of Fluoride reagent $(\mathrm{F}-1)$ was placed in a test tube; $5.0 \mathrm{ml}$ of the pretreated sample was added in the test tube and mixed and then had a 5 minutes reaction time before it was transferred in a10mm culvert and then it was placed in the photometer (Spectroquant 300) for analysis.

Chloride: $5.0 \mathrm{ml}$ of the pretreated sample was placed into a test tube; $2.5 \mathrm{ml}$ of Copper reagent $(\mathrm{Cl}-1)$ was added to the test tube and mixed; $0.5 \mathrm{ml}$ of Copper reagent $(\mathrm{Cl}-2)$ was added and mixed; it had a reaction time of 1 minute before it was transferred into the $100 \mathrm{~mm}$ Culvert and then it was placed in the photometer (Spectroquant 300) for analysis.

Nitrite: $5.0 \mathrm{ml}$ of the pretreated sample was placed into a test tube; 1 level blue micro spoon of Nitrite reagent was added and have a reaction time of $10 \mathrm{mins}$ and then it was transferred in a $10 \mathrm{~mm}$ culvert before it was placed into the photometer (Spectroquant 300) for analysis.

Total Hardness: $1.0 \mathrm{ml}$ of the pretreated sample was placed in a test tube; $1.0 \mathrm{ml}$ of Total hardness reagent $(\mathrm{H}-1 \mathrm{~K})$ was added and mix and then it had a reaction time of 3 minutes before it was transferred into the culvert and then place in the photometer (Spectroquant 300) for analysis.

Bacteria: The microbiological analysis was carried out by using the following media; plate count agar, nutrient agar, Lactose broth, and Eosin methylene blue agar. All the media was prepared according to the manufacturer's specifications. A serial dilution method was used for the total viable count while the total coliform counts were carried out by the standard plate count technique using MacConkey agar, and fecal coliform was determined using Eosin methylene blue medium using pour plate technique. The Confirmations of the isolates was done by using Lactose broth at $44.5^{\circ}$ c. (Agwu A., Avoaja A. G., Kalu A. U, 2013).

\subsection{Data Analysis Procedures}

Microsoft office 2016 was used to analyze the data. The data was analyzed by using tables and graphical analysis in Microsoft office word 2016. Statistical tools such as mean, mode average, and Standard Deviation were also used to analyze the data.

\section{DATA PRESENTATION AND INTERPRETATION}

\subsection{Data Presentation}

This table shows the concentration of the physiochemical and microbiological parameters of the five brands of sachet water that were experimentally analyzed.

Table 1 shows the Concentrations of the Physiochemical Parameters of the five brands of sachet water

\begin{tabular}{|c|c|c|c|c|c|c|c|}
\hline Parameters & $\begin{array}{c}\text { Prosperity } \\
(\mathrm{mg} / \mathrm{l})\end{array}$ & E\&F $(\mathrm{mg} / \mathrm{l})$ & $\begin{array}{c}\text { Gentle } \\
(\mathrm{mg} / \mathrm{l})\end{array}$ & $\begin{array}{c}\text { Best Aqua } \\
(\mathrm{mg} / \mathrm{l})\end{array}$ & $\begin{array}{c}\text { Royalty } \\
\text { Aqua } \\
(\mathrm{mg} / \mathrm{l})\end{array}$ & $\begin{array}{c}\text { WHO } \\
\text { Standards } \\
(2012)(\mathrm{mg} / \mathrm{l})\end{array}$ \\
\hline Copper & 0.08 & 0.05 & 0.07 & 0.10 & 0.10 & $\leq .01$ \\
$(1987)(\mathrm{mg} / \mathrm{l})$
\end{tabular}

Source: Researcher's field data, 2019 
Table 1 shows a tabular summary of the concentrations of the Physiochemical Parameters of the five brands of sachet water in relation to the WHO (2012) and the Liberia Water Quality Standards (1987) for drinking water.
Graphical Illustration of table 1 shows the Physiochemical Parameters of the five brands of sachet water

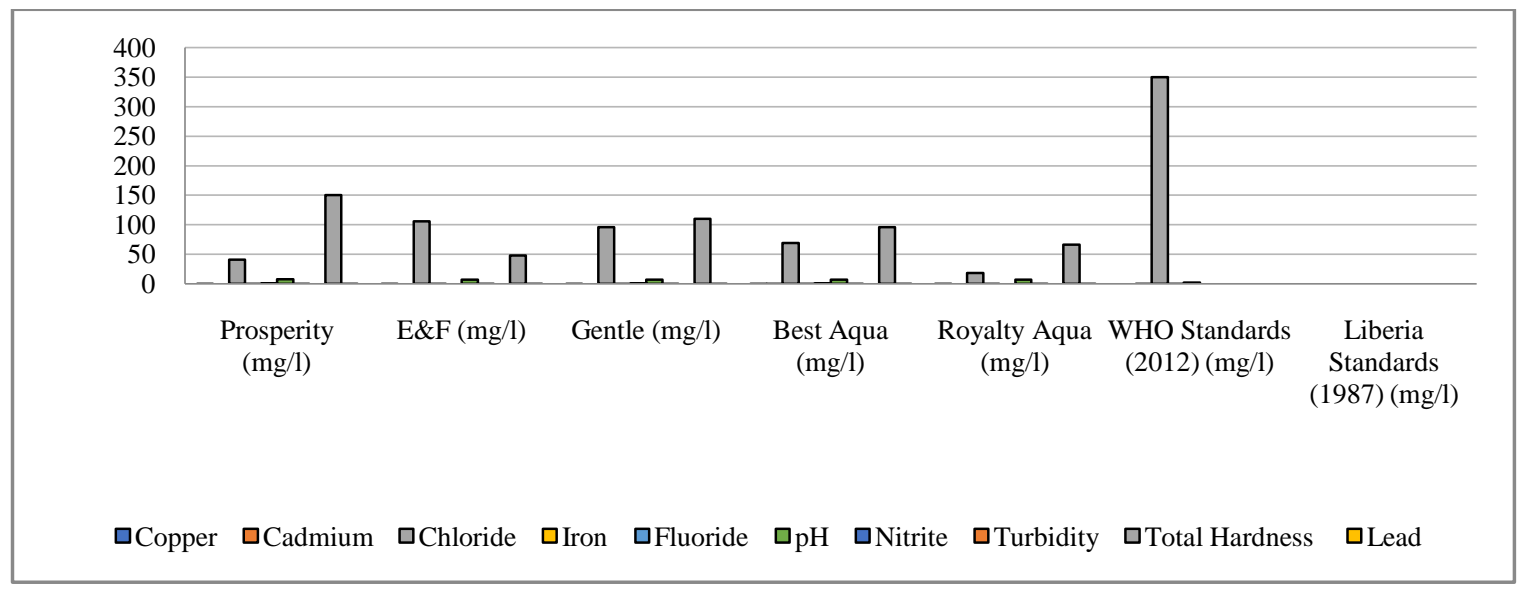

Table 2 shows the Concentrations of the Microbial Parameters of the five brands of sachet water

\begin{tabular}{|c|c|c|c|c|c|c|c|}
\hline Parameters & $\begin{array}{c}\text { Prosperity } \\
(\mathrm{cfu} / \mathrm{ml})\end{array}$ & $\begin{array}{c}\text { E\&F } \\
(\mathrm{cfu} / \mathrm{ml})\end{array}$ & $\begin{array}{c}\text { Gentle } \\
(\mathrm{cfu} / \mathrm{ml})\end{array}$ & $\begin{array}{c}\text { Best Aqua } \\
(\mathrm{cfu} / \mathrm{ml})\end{array}$ & $\begin{array}{c}\text { Royalty } \\
\text { Aqua } \\
(\mathrm{cfu} / \mathrm{ml})\end{array}$ & $\begin{array}{c}\text { WHO } \\
\text { Standards } \\
(2012) \\
(\mathrm{cfu} / \mathrm{ml})\end{array}$ & $\begin{array}{c}\text { Liberia } \\
\text { Standards } \\
(1987) \\
(\mathrm{cfu} / \mathrm{ml})\end{array}$ \\
\hline E.coli & 0.00 & 0.00 & 0.00 & $<1.0 \times 10^{\circ}$ & 0.00 & 0.00 & 0.00 \\
\hline Coliform & 0.00 & 0.00 & 0.00 & 0.00 & 0.00 & 0.00 & 0.00 \\
\hline Fecal Coliform & 0.00 & $<1.0 \times 10^{\circ}$ & 0.00 & 0.00 & 0.00 & 0.00 & 0.00 \\
\hline Salmonella & 0.00 & 0.00 & 0.00 & 0.00 & 0.00 & 0.00 & 0.00 \\
\hline
\end{tabular}

Source: Researcher's field data, 2019

Table 2 shows a tabular summary of the concentration of the Microbial Parameters of the five brands of sachet water in relation to the WHO (2012) water quality standards and the Liberia Water Quality Standards (1987) for drinking water.
Graphical Illustration of table 2 shows the detection of the Microbial Parameters of the five brands of sachet water

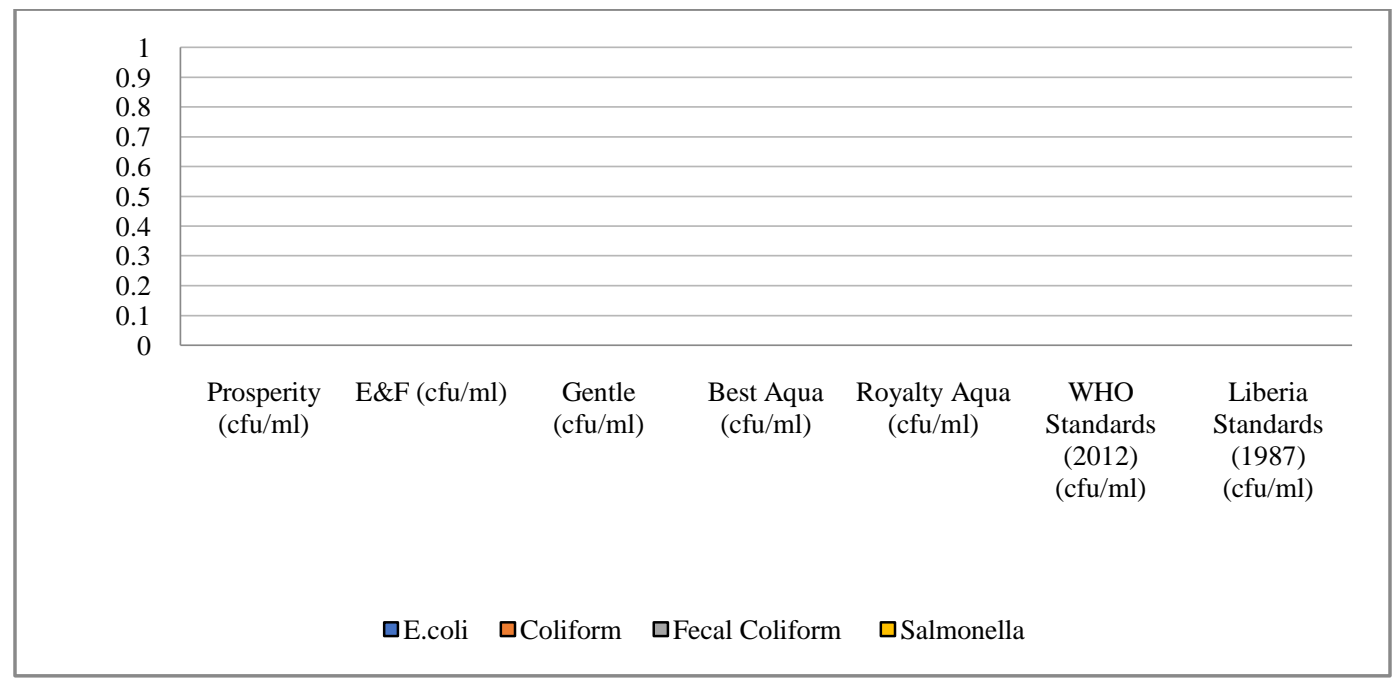

Table 3 shows the concentrations of the Physiochemical parameters that met the WHO (2012) water quality standards and the Liberia Water Quality Standards for drinking water amongst the five brands of sachet water 


\begin{tabular}{|c|c|c|c|c|c|c|c|}
\hline Parameters & $\begin{array}{c}\text { Prosperity } \\
(\mathrm{mg} / \mathrm{l})\end{array}$ & $\begin{array}{c}\text { E\&F } \\
(\mathrm{mg} / \mathrm{l})\end{array}$ & $\begin{array}{c}\text { Gentle } \\
(\mathrm{mg} / \mathrm{l})\end{array}$ & $\begin{array}{c}\text { Best Aqua } \\
(\mathrm{mg} / \mathrm{l})\end{array}$ & $\begin{array}{c}\text { Royalty } \\
\text { Aqua } \\
(\mathrm{mg} / \mathrm{l})\end{array}$ & $\begin{array}{c}\text { WHO Standards } \\
(2012)(\mathrm{mg} / \mathrm{l})\end{array}$ & $\begin{array}{c}\text { Liberia } \\
(1987)(\mathrm{mg} / \mathrm{l})\end{array}$ \\
\hline Cadmium & 0.00 & 0.00 & 0.00 & 0.010 & 0.00 & 0.00 & 0.00 \\
\hline Chloride & 41 & 106 & 96 & 69 & 18 & 0.00 & 0.00 \\
\hline Iron & 0.10 & 0.04 & 0.05 & 0.05 & 0.05 & 0.00 & 0.00 \\
\hline Fluoride & 0.32 & 0.00 & 0.20 & 0.20 & 0.00 & 0.00 & 0.00 \\
\hline $\mathrm{pH}$ & 7.2 & 7.0 & 68 & 68 & 7.15 & 0.00 & 0.00 \\
\hline Turbidity & 0.6 & 0.00 & 0.00 & 0.00 & 0.00 & 0.00 & 0.00 \\
\hline Total Hardness & 150 & 48 & 110 & 96 & 66 & 0.00 & 0.00 \\
\hline
\end{tabular}

Source: Researcher's field data, 2019

Table 3 shows the concentration of the Physiochemical parameters that meet the WHO Standards amongst the five brands of sachet water; which indicated that Cadmium, Chloride, Iron, Fluoride, pH, Turbidity, and Total Hardness met the acceptable standards for drinking water in relation to WHO (2012) water quality standards and the Liberia Water Quality Standards for drinking water.
Graphical illustration of table 3 shows the concentrations of the Physiochemical parameters that met the WHO (2012) water quality standards and the Liberia Water Quality Standards for drinking water amongst the five brands of sachet water

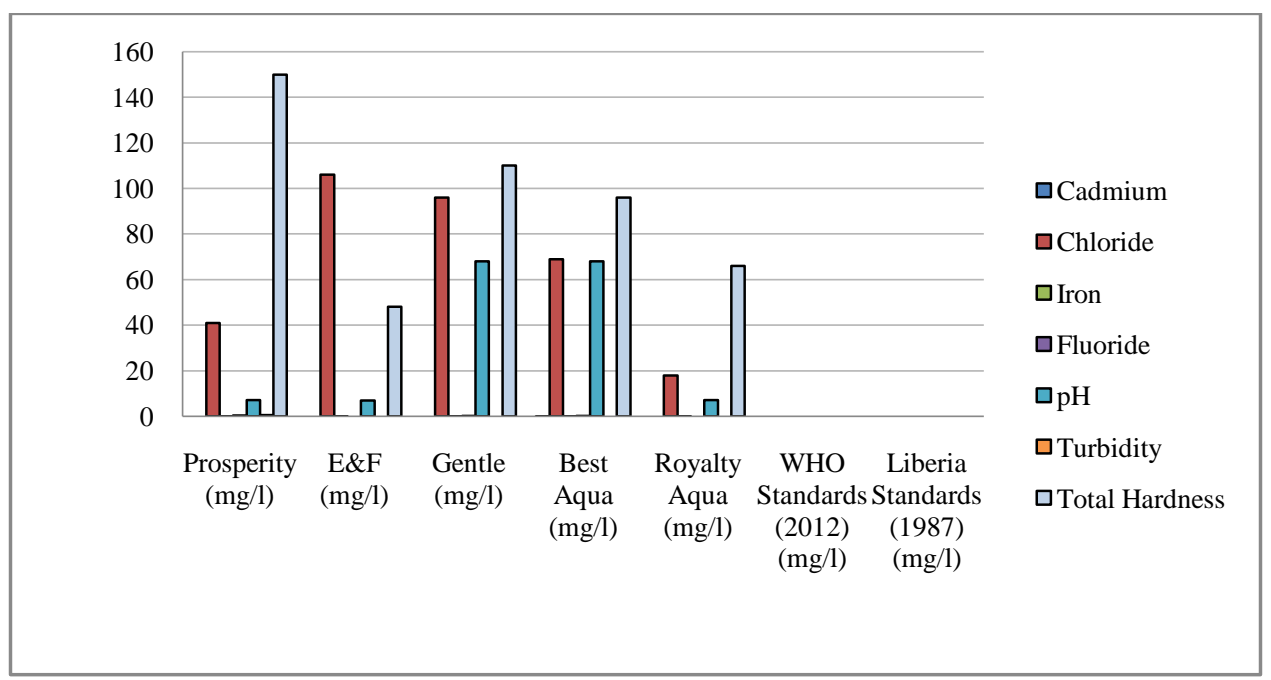

Table 4 shows the concentrations of the Physiochemical parameters that are above the WHO (2012) and the Liberia Water Quality Standards (1987) for drinking water amongst the five brands of sachet water

\begin{tabular}{|c|c|c|c|c|c|c|c|}
\hline Parameters & $\begin{array}{c}\text { Prosperity } \\
(\mathrm{mg} / \mathrm{l})\end{array}$ & $\begin{array}{c}\text { E\&F } \\
(\mathrm{mg} / \mathrm{l})\end{array}$ & $\begin{array}{c}\text { Gentle } \\
(\mathrm{mg} / \mathrm{l})\end{array}$ & $\begin{array}{c}\text { Best Aqua } \\
(\mathrm{mg} / \mathrm{l})\end{array}$ & $\begin{array}{c}\text { Royalty } \\
\text { Aqua } \\
(\mathrm{mg} / \mathrm{l})\end{array}$ & $\begin{array}{c}\text { WHO } \\
\text { Standards } \\
(2012)(\mathrm{mg} / \mathrm{l})\end{array}$ & $\begin{array}{c}\text { Liberia } \\
\text { Standards } \\
(1987)(\mathrm{mg} / \mathrm{l})\end{array}$ \\
\hline Copper & 0.08 & 0.05 & 0.07 & 0.10 & 0.10 & 0.00 & 0.00 \\
\hline Nitrite & 0.06 & 0.09 & 0.20 & 0.06 & 0.03 & 0.00 & 0.00 \\
\hline Lead & 0.07 & 0.10 & 0.07 & 0.15 & 0.02 & 0.00 & 0.00 \\
\hline
\end{tabular}

Source: Researcher's field data, 2019

Table 4 shows the concentration of the Physiochemical parameters that do not meet the WHO Standards amongst the five brands of sachet water; which indicated that Copper, Nitrite, and Lead were above the acceptable standards for both WHO (2012) and the Liberia Water Quality Standards (1987) for drinking water.
Graphical illustration of table 4 shows concentrations of the Physiochemical parameter that are above the WHO (2012) and the Liberia Water Quality Standards (1987) for drinking water amongst the five brands of sachet water 


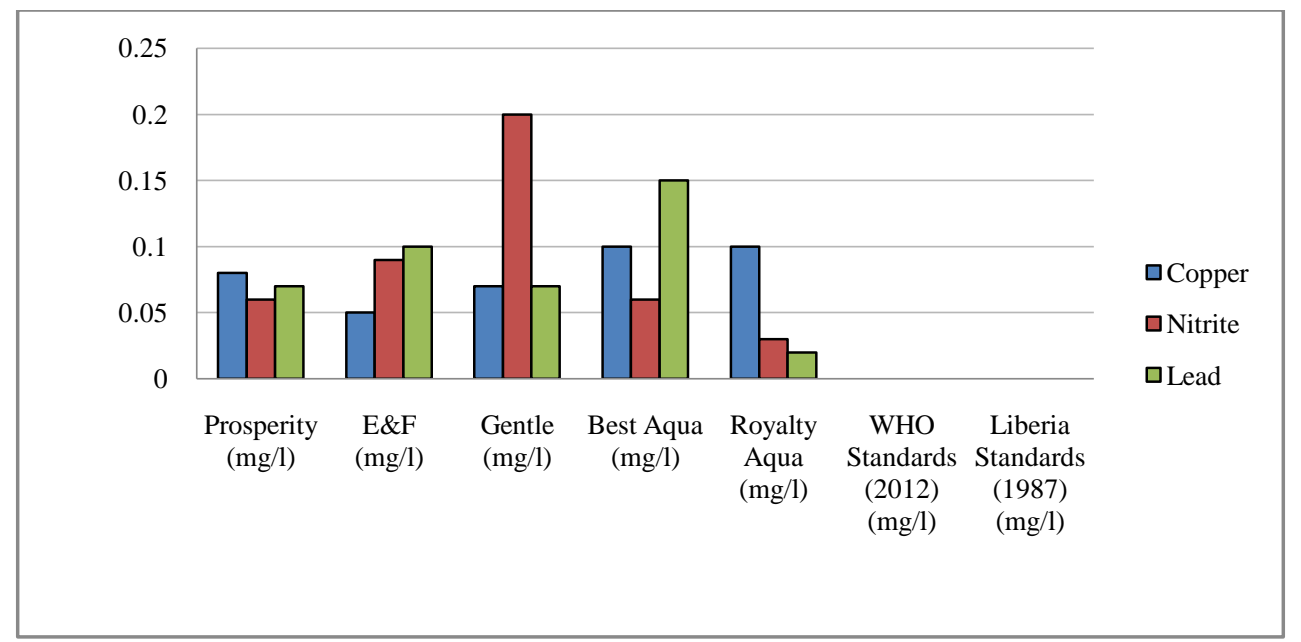

Table 5 shows the concentration of the Microbiological parameter that met the WHO (2012) water quality standards and the Liberia Water Quality standards (1987) for drinking water amongst the five brands of sachet water

\begin{tabular}{|c|c|c|c|c|c|c|c|}
\hline Parameters & $\begin{array}{c}\text { Prosperity } \\
(\mathrm{cfu} / \mathrm{ml})\end{array}$ & $\begin{array}{c}\text { E\&F } \\
(\mathrm{cfu} / \mathrm{ml})\end{array}$ & $\begin{array}{c}\text { Gentle } \\
(\mathrm{cfu} / \mathrm{ml})\end{array}$ & $\begin{array}{c}\text { Best Aqua } \\
(\mathrm{cfu} / \mathrm{ml})\end{array}$ & $\begin{array}{c}\text { Royalty } \\
\text { Aqua } \\
(\mathrm{cfu} / \mathrm{ml})\end{array}$ & $\begin{array}{c}\text { WHO } \\
\text { Standards } \\
(2012)\end{array}$ & $\begin{array}{c}\text { Liberia } \\
\text { Standards } \\
(1987)\end{array}$ \\
\hline Coliform & 0.00 & 0.00 & 0.00 & 0.00 & 0.00 & 0.00 & 0.00 \\
\hline Salmonella & 0.00 & 0.00 & 0.00 & 0.00 & 0.00 & 0.00 & 0.00 \\
\hline
\end{tabular}

Source: Researcher's field data, 2019

Table 5 shows the Microbiological parameter that is in range with the WHO (2012) water quality standards and the Liberia Water Quality Standards (1987) for drinking water amongst the five brands of sachet water; which indicated that Coliform and Salmonella met the acceptable microbiological standards for both WHO (2012) water quality standards and the Liberia Water Quality Standards (1987) for drinking water.
Graphical illustration of table 5that shows the Microbiological parameter that is in range with the WHO (2012) water quality standards and the Liberia Water Quality Standards (1987) for drinking water amongst the five brands of sachet water

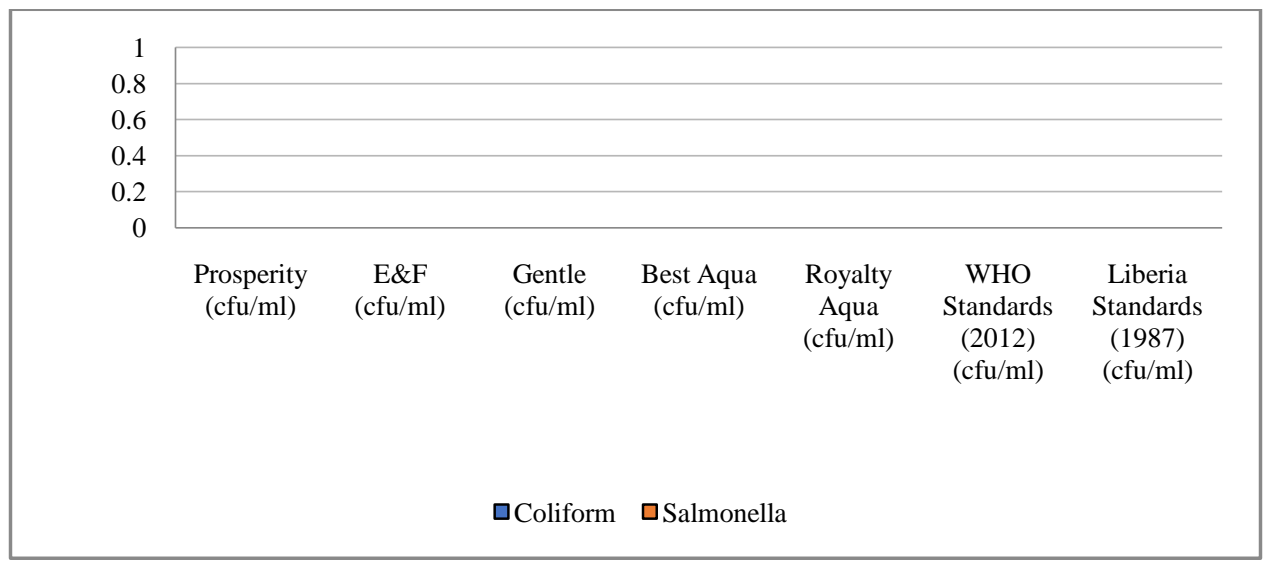

Table 6 shows the concentration of the Microbiological parameter that are above the WHO (2012) and the Liberia Water Quality Standards (1987) for drinking water amongst the five brands of sachet water

\begin{tabular}{|c|c|c|c|c|}
\hline Parameters & $\begin{array}{c}\text { Best Aqua Mineral } \\
\text { Water (BAMW) } \\
(\mathrm{cfu} / \mathrm{ml})\end{array}$ & $\begin{array}{c}\text { E\&F Mineral Water } \\
(\text { E\&FMW) }(\mathrm{cfu} / \mathrm{ml})\end{array}$ & WHO (2012) $(\mathrm{cfu} / \mathrm{ml})$ & $\begin{array}{c}\text { Liberia Water Quality } \\
\text { Standards }(1987) \\
(\mathrm{cfu} / \mathrm{ml})\end{array}$ \\
\hline E. coli & $<1.0 \times 10^{\circ}$ & 0.00 & 0.00 & 0.00 \\
\hline Fecal Coliform & 0.00 & $<1.0 \times 10^{\circ}$ & 0.00 & 0.00 \\
\hline
\end{tabular}

Source: Researcher's field data, 2019 
Table 6 shows the Microbiological parameter that was above the WHO (2012) water quality standards and the Liberia Water Quality standards (1987) for drinking water amongst the five brands of sachet water; which indicated that E. coli and Fecal Coliform were above the acceptable microbiological standards for both WHO (2012) and the Liberia Water Quality Standards (1987) for drinking water.
Graphical illustration of table 6 shows the concentration of the Microbiological parameter that are above the WHO (2012) and the Liberia Water Quality Standards (1987) for drinking water amongst the five brands of sachet water

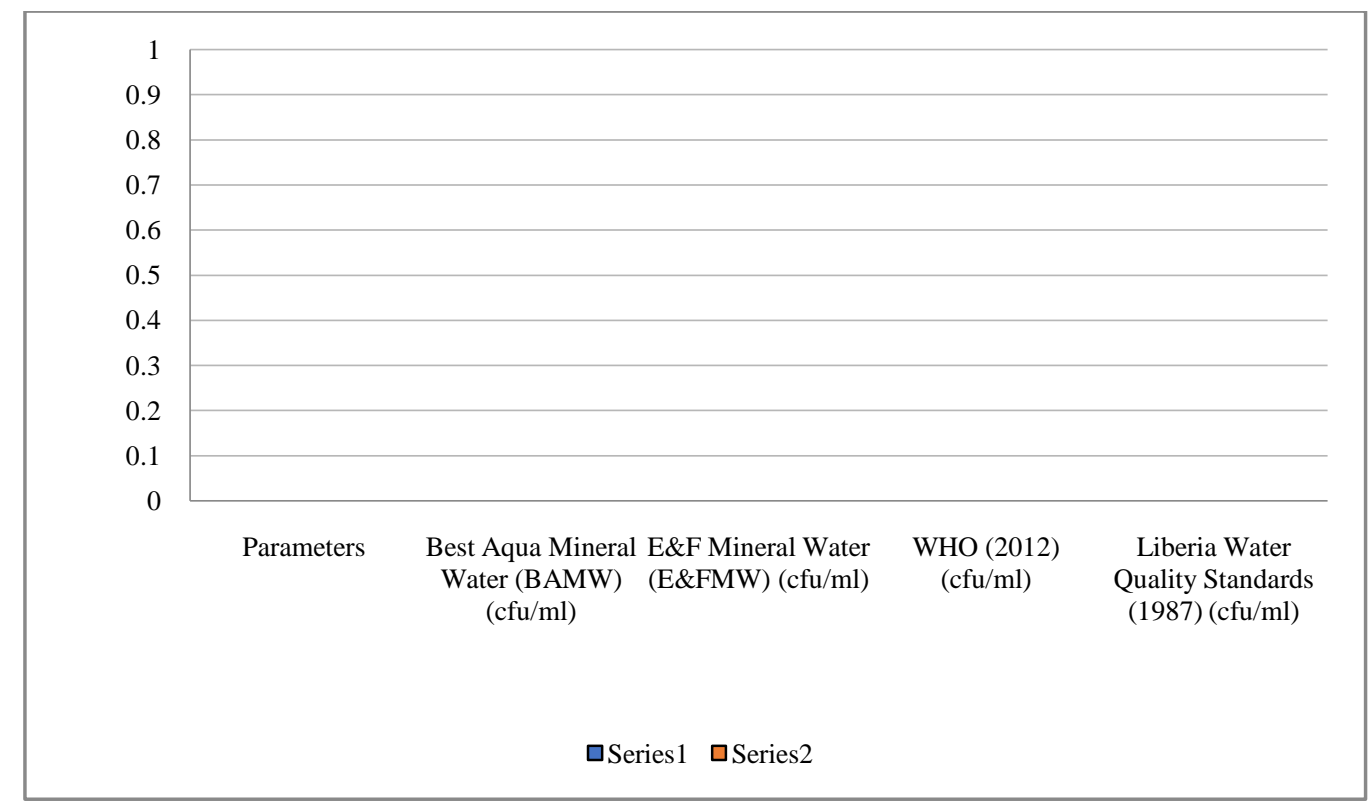

\subsection{Findings}

Below are detailed discussions of the findings from the data that were generated during the physiochemical and microbiological analysis:

Table 11.0 shows the concentration of the physiochemical parameters in the five selected brands of sachet water that were under study. The Copper contents in the samples of the five selected brands of sachet water were above the stipulated WHO, (2012) water quality standards for drinking water but all of samples of the sachet water brands fell within the range of the Liberia Water Quality Standards, (1987). Dissolved copper sometimes imparts a light blue or blue-green color and an unpleasant metallic, bitter taste to drinking water (ATSDR, 2002). It is a potential health hazard that causes various health problems when people are exposed to it at levels above the permissible value. Short periods of exposure can cause gastrointestinal disturbance, including nausea and vomiting while the use of water whose copper level exceeds the maximum value over many years causes liver or kidney damage (EPA, 2011b; WHO, 2004b).

The concentrations of Cadmium, Chloride, Iron, Fluoride, $\mathrm{pH}$, Turbidity, and Total Hardness in the samples of the five different brands of sachet water met the stipulated standards for drinking water of both WHO, (2012) and the Liberia Water Quality Standards, (1987).

The concentrations of Nitrite contents in E\&F Mineral Water (E\&FMW), Best Aqua Mineral Water (BAMW), and Royalty Aqua Mineral Water (RAMW) met the stipulated standards for both WHO, (2012) and the Liberia Water Quality standards for drinking water but the concentrations of Nitrite contents in Prosperity Mineral Water (PMW) and Gentle Mineral Water (GMW) were above the stipulated standards for both WHO, (2012) water quality standards and the Liberia Water Quality Standards for drinking water. This is of serious health significance. Nitrites react directly with hemoglobin in human blood to produce methemoglobin, which destroys the ability of blood cells to transport oxygen. This condition is especially serious in babies less than three months of age as it causes a condition known as methemoglobinemia or blue baby disease. Water with nitrite levels exceeding $0.1 \mathrm{mg} / \mathrm{l}$ should not be given to babies. (Martins Okechukwu Isikwu \& Ada Okey Chikezie, 2014). The major sources of nitrite in drinking water are runoff from fertilizer use, leaching from septic tanks, sewage and erosion of natural deposits (Cam et al., 2008). Some dwellers of the Gaye Town community still use public latrines (pit toilets), thus there could be possible seepage of nitrites from such pits into the underground water especially as the water table of the zone is high. 
The concentrations of Lead contents in Prosperity Mineral Water (PMW), E\&F Mineral Water (E\&FMW), Gentle Mineral Water (GMW), and Royalty Aqua Mineral Water (RAMW) met the stipulated standards for both WHO, (2012) and the Liberia Water Quality standards for drinking water. However, the concentrations of Lead contents in Best Aqua Mineral Water (BAMW) were above the stipulated standards for both WHO, (2012) and the Liberia Water Quality Standards for drinking water. The presence of lead in one out of the five different sachet water brands is of serious health implication especially as the values obtained were above the WHO, (2012) water quality standards and the Liberia water quality standards for drinking water. Prolonged drinking of such waters by children and expectant mothers could result in certain ailments which include IQ loss (Tellez-Rojo et al., 2006; Lanphear et al., 2005; Canfield et al., 2003). As more lead is consumed in lead-contaminated water the greater the risk of having lead-associated ailments. It has been shown in some studies that the effects of early childhood exposure to lead on neurodevelopment persist into the second decade of life (Ris et al., 2004; Wasserman et al., 2000; Fergusson et al., 1997; Bellinger et al., 1992). Some adverse health conditions have been linked to prenatal lead exposure to mother and infant. These include fertility problems, hypertension, and infant neurodevelopment (Bellinger, 2005).

The results of the microbiological examinations of the sachet water brands are shown in table 12.0 The results revealed that there were no bacteria present in Prosperity Mineral Water (PMW), Gentle Mineral Water (GMW), and Royalty Aqua Mineral Water (RAMW).

The results also revealed the presence of E.coli in Best Aqua Mineral Water (BAMW) and Fecal Coliform in E\&F Mineral Water (E\&FMW) which did not meet the WHO, (2012 water quality standards and the Liberia Water quality standards, (1987) for drinking water. The presence of Fecal coliforms and E.coli in the water samples is an indication of the poor sanitary levels maintained by the producers, and it could be that the source of water has been contaminated with human or animal feces since E. coli is a normal flora organism in man and animals (Trevett et al., 2005). The incidence of E. coli in boreholes is, therefore, a concern as such sources are usually regarded as "safe" (Taulo et al., 2008). The need for proper treatment of water should always be emphasized. Various water sources have been implicated in some outbreaks of diseases especially in developing countries where the supply of adequately treated water is a problem.

\section{SUMMARY/CONCLUSIONS/RECOMMENDATIONS}

\subsection{Summary}

Water is said to be portable when its physical, chemical, and microbiological qualities conform to a specified standard. To achieve such a standard, raw water is subjected to purification processes that range from simple long-term storage to enable sedimentation of some suspended solids to aeration, coagulation, flocculation, filtration and disinfection among other treatments (Ajewole, 2005). Water plays a major biochemical role in living things. It provides a medium for the transportation, assimilation, and utilization of important nutrients in human beings. This implies that if the water is polluted, biochemical processes in the body may be hindered (Anduang O. Odiongenyi, 2014). Therefore, research was conducted in the Gaye Town community to conduct an analytical assessment on the Physiochemical and Microbiological parameters in the most popular five different brands of sachet water that are sold in the study area. The random sampling technique was used with an experimental design to conduct the analytical research. The findings of the research indicated that none of the brands were $100 \%$ safe for consumption and needs proper treatment and regulatory monitoring in order to meet the World Health Organization (2012) water quality standards and the Liberia water quality standards (1987) for drinking and also to be safe for consumption.

\subsection{Conclusion}

To conclude, the research was successfully conducted at the National Standards Laboratory of Liberia. None of the samples of the various brands of sachet water from the study area met all the parameters of the water quality standards for drinking water for both the Physiochemical and Microbiological parameters in relation to the World Health Organization (2012) drinking water quality standards and the Liberia Water Quality Standards (1987) for drinking water which implies that is not safe for consumption. The concentration of Copper in all of the samples of the five brands of sachet water did not meet stipulated water quality standards. However, Prosperity Mineral Water (PMW) Royalty Aqua Mineral Water (RAMW) is the safest amongst the five brands of sachet water that were under study because they are bacteria-free and only have an increase in the Copper content.

\subsection{Recommendation}

Water is said to be portable when its physical, chemical, and microbiological qualities conform to a specified standard (Ajewole, 2005). Therefore, it is recommended that sachet water producers should have their water tested regularly especially in areas where fertilizers are commonly used and where latrines (pit holes) are prevalent; There should be awareness to educate the public on the need for sachet water that are meant for drinking or consumption to meet safety requirements and quality standards; regulatory agencies should intensify their inspection activities especially by paying unscheduled visits to facilities to validate production processes and approve borehole locations; and also regulatory authority should revise or update Liberia's Water Quality Standards for drinking water.

\section{REFERENCES}

[1] Ackah-Arthur M, Amin AK, Gyamfi ET, Acquah J, Nyarko E S, Kpattah SE, Brown SE, Hanson JEK, Fianco JR and Zakaria N (2012). Assessment of the quality of sachet water consumed in 
urban townships of Ghana using physico-chemical indicators: A preliminary study. Advances in Applied Science Research 3: 2120-2127. 2. Adegoke OO, Bamigbowu EO, Oni ES and Ugbaja $\mathrm{KN}$ (2012). Microbiological examination of sachet water sold in Aba, Abia State, Nigeria. Global Research Journal of Microbiology 2: 62-66.

[2] Adetunde LA, Sackey I, Elvis BB and Afarawoye AE (2014). Bacteriological quality of sachet water produced and sold in the Bolgatanga Municipal in the Upper East Region of Ghana. International Journal of Modern Social Sciences 3: 36-43.

[3] Adewoye AO, Adewoye SO and Opasola OA (2013). Microbiological examination of sachet water experimentally exposed to sunlight. International Journal of Pure and Applied Sciences and Technology 18: 36-42

[4] Ahimah, J.K., and Ofosu, S.A. (May 2012). Evaluation of the quality of sachet water vended in the New Juaben municipality of Ghana. International Journal of Water Resources and Environmental Engineering Vol. 4(5), 134-138.

[5] Akinde SB, Nwachukwu MI and Ogamba AS (2011). Storage effects on the quality of sachet water produced within Port Harcourt metropolis, Nigeria. Journal of Biological Sciences 4: 157-164.

[6] Anuobi CC, Onajole AT and Ogunnowo BE (2006). Assessment of the quality of packaged water on sale in Onitsha metropolis. Nigerian Quarterly Journal of Hospital Medicine 16: 56-59. 7. Anyamene NC and Ojiagu DK (2014). Bacteriological Analysis of sachet water sold in Akwa Metropolis, Nigeria. International Journal of Agriculture and Biosciences 3: 120-122.

[7] Aroh KN, Eze EM, Ukaji D, Wachuku CK, Gobo AE, Abbe SD, Teme SC and Igoni AH (2013). Health and environmental components of sachet water consumption and trade in Aba and Port Harcourt, Nigeria. Journal of Chemical Engineering and Material Science 4: 13-22.

[8] Ato, J.A. and Ayua, I.J. (2013). Design and Construction of a potable water treatment unit for Domestic Usage. Unpublished final Year project submitted to the Dept. Agricultural and Environmental Engineering, University of Agriculture Makurdi Nigeria

[9] Bain R, Cronk R, Wright J, et al: Fecal contamination of drinking water in low- and middle-income countries: a systematic review and meta-analysis. PLoS med. 2014; 11(5): e11001644

[10] Balogun SA, Akingbade AO, Oyekunle MA and Okerentugba PO (2014). Physiochemical and Microbiological profile of drinking water sold in Abeokuta, Ogun State, Nigeria. Nature and Science 12: $103-105$

[11] Banu N and Menakuru H (2010). Enumeration of microbial contaminants in sachet water: A public health challenge. Health 6: 582-588.

[12] Bharath J, Mosodeen M, Motilal S, Sandy S, Sharma S, Tessaro T, Thomas K, Umamaheswaram M, Simeon D and Adesiyan AA (2003). Microbiological quality of domestic and imported brands of bottled water in Trinidad. International Journal of Food Microbiology 81: 53-62.

[13] Boubetra A, Allaert CC and Feinberg M (2011). Validation of alternative methods for the analysis of drinking water and their application to Escherichia coli. Applied Environmental Microbiology 77: 3360-3367. 13. Cabral JPS (2010). Water Microbiology: Bacterial pathogens and water. International Journal of environmental Research and Public Health 7: 36573703

[14] Danso-Boateng E and Frimpong IK (2013). Quality analysis of plastic sachet and bottled water brands produced or sold in Kumasi, Ghana. International Journal of Development and Sustainability 4: 2222-2232.

[15] Defives C, Guyard S, Oulare MM and Hirnez JP (1999). Total counts, culturable and viable and non-culturable microflora of a french mineral water: A case study. Journal of Applied Microbiology 86: 1033-1038.

[16] Chikezie, A. (2012). Quality Analysis of Selected Sachet water sold in Bauchi Metropolis, Nigeria. An Unpublished PGD Thesis submitted to the Dept. Agricultural and Environmental Engineering, University of Agriculture Makurdi Nigeria

[17] Dada A.C. (2009). Sachet water phenomenon in Nigeria: Assessment of the potential Health impacts. African Journal of Microbiology Research 3(1). 015-021.

[18] Fewtrell, L., \& Bartram, J. (2001). Water Quality "Guidelines, Standards and Health: Assessment of risk and risk management for water-related infectious disease". World Health Organization.

[19] Fong, T.T., L.S. Mansfield, D.L. Wilson, D.J. Schwab, S.J. Molloy and J.B. Rose (2007). Massive microbiological ground water contamination associated with a water borne outbreak in Lake Erie, South Bass Island, Ohio. Environ. Health Perspect, 155: 856-864.

[20] Gadgil A. and Derby E.(2003). Providing Safe Drinking Water to 1.1 billion unsaved people. Paper No, 70492

[21] Hunter RR and Burge SH (1987). The bacterial quality of bottled natural mineral waters. Epidemiology and Infection 99: 439-443

[22] Isikwue, M.O., Iorver, D. \& Onoja, S.B. (2011). Effect of Depth on Microbial Pollution of Shallow Well in Makurdi Metropolis, Benue State, Nigeria. British Journal of Environment \& Climate Change 1(3): 6673. www.sciencedomain.org

[23] Izah SC, Ineyougha ER: A review of the microbial quality of portable water sources in Nigeria. J Adv Biol Basic Res. 2015; 1(1): $12-19$

[24] J. C. Onweluzo and C. A. Akuagbazie, 2010, Assessment of the quality of bottled and sachet water sold in Nsukka town, Agro science J. Tropical Agriculture, Food, Environment and Extension, 9(2): $104-110$.

[25] Kjellen, M., \& McGranahan, G. (2006). Informal water vendors and the urban poor, Water 1Discussion Paper 3, International Institute for Environment and Development (IIED), London.

[26] K. Rajim, P. Roland, C. John and R. Vincent, 2010, Microbiological and Physicochemical analysis of drinking water in Georgetown Guyana, Nature and Science,(8): $261-265$

[27] Lowry, C. S. and Fienen, M. N. (2013). Crowd Hydrology: Crowdsourcing Hydrologic Data and Engaging Citizen Scientists. Ground Water, 51: 151-156.

[28] Liberia Institute of Statistics and Geo-Information Sciences. (LIGIS). (2014). Population by County, District and Towns.

[29] McKee, J. E., \& Wolfe, H. W (1 June 1974). Water Quality Criteria. California State Water Resources Control Board.

[30] Mustapha, S. and Adamu E. A. (1991) Discussion on Water Problems in Nigeria: Focus on Bauchi State. National Research Institute.

[31] Mojekeh MO and Eze PAO (2011). The environmental impact of production and sales of sachet water in Nigeria. African Research Review 5: 479-492

[32] Njoku G. and Osondu, A. (2007). New Standard for Drinking Water Qualify in Nigeria: A guide to ensure the safely of Drinking water and protect Public Health. http://www.unicef.org/nigeria/wash-2165.html [10]. Obadare F.O. (1995). Microbiological Analysis of Bottled Water Unpublished data Department of BioChemistry Federal University of Technology Akure, Nigeria.

[33] O. A. Adegoke, E.O. Bamigbowu, and K.S. Okpo, 2011, Bacteriological assessment of borehole water in Oyigbo town, Rivers State, Nigeria. International Journal of Applied Biological Research, 3(1):47 - 55.

[34] Ogamba, A.S. (2004). Packaged drinking water, how safe? Professionalism IPAN News.

[35] Ombaka, O. and Gichumbi, J.M. (2012). Investigation of Physicochemical and Bacteriological Charateristics of Water Samples from Irigu River Meru South, Kenya. [3]. Kegley, E.S. and Andrew J. (1998). The Chemistry of Water. Chemical Parameters for Water Quality, University Science Books, California: 2nd Edition, PP: 13-162.

[36] Omalu CI, Eze GC, Olayemi K, Gheri S, Adeniran LA, Ayanwale AV, Mohamed AZ and Chukwuemeka V (2010). Contamination of sachet water in Nigeria: Assessment and health impact. The Online Journal of Health and Allied Sciences 9: 15-20. 
[37] Pierre P (1999). Poor efficacy of residual chlorine disinfectant in drinking water to inactivate water borne pathogens in distribution systems. Canada Journal of Microbiology 45: 709-715.

[38] Rahmanian, N., Ali, S.H. B., Homayoonfard, M., Ali, N. J., Rehan, M., Sadef, Y., and Nizami, A.S. (2015). Analysis of Physiochemical Parameters to Evaluate the Drinking Water Quality in the State of Perak, Malaysia, Journal of Social Sciences, $6(3), 1-10$.

[39] Rutz D (1996). Pure water vending machines may not be so pure. CNN: Food and health. May 2.

[40] Uduma, M.B. (2014). Determination of heavy metals in Challawa River. Unpublished Bayero University B.Sc. Project Pg. 20-30.

[41] SON. (2007). Nigerian Standards for Drinking Water Quality. Nigerian Industrial Std, NIS 554, Published by the Standard Organisation. of Nigeria, 13/14 V.A. Street off Admiralty way, Lekkis, Lagos Nigeria, (2007).

[42] Sakyi, P. A., \& Asare, R. (2012). Impact of Temperature on Bacterial Growth and Survival in Drinking-Water Pipes. Maxwell Scientific Organization.

[43] Stoler J, Weeks JR, Fink G: NIH Public Access. Changes. 2012; 29: 997-1003.
[44] United States Environmental Protection Agency (USEPA) (2002). Setting Standard for safe Drinking Water. http:www/epa. Gov/safe water. Accessed on 10/10/2011

[45] World Health Organization (WHO). (1996). Guidelines for drinking water quality. Health criteria and other information. Int. Prog. Chem. Saf., 2: 973.

[46] World Health Organization (WHO). (2001). Physical and Chemical Standard: Standard for Drinking Water.

[47] World Health Organization (WHO). (2011). Guidelines for Drinking Water Quality. World Health Organization, Geneva.

[48] World Health Organization (WHO). (2012). Guidelines for Drinking Water Quality. World Health Organization, Geneva.

[49] Warren, V. (Jr) and Mark, J.H. (1998). Water Supply and Pollution Control. A guide line for Drinking Water Quality, California : Addison Wesley longman inc, pp: 876.

[50] WHO (World Health Organisation), (2004). Guildelines for Drinking Water Quality. Vol. 2 2nd Edition

[51] World Health Organization WHO (2004). Water sanitation and hygiene links to health: Facts and figures updated November 2004. Available on www.who.int/water_sanitation_health/publications/ facts2004/en.print. www.epa.gov/safewater/mcl.html. 
International Journal of Research and Scientific Innovation (IJRSI) |Volume IX, Issue I, January 2022| ISSN 2321-2705

APPENDIXES:

WHO, 2012 Water Quality Guideline for Drinking Water:

\begin{tabular}{|c|c|c|}
\hline Parameter & Unit & WHO \\
\hline Copper & $\mathrm{mg} / \mathrm{L}$ & 0.01 \\
\hline Cadmium & $\mathrm{mg} / \mathrm{L}$ & 0.01 \\
\hline Chloride & $\mathrm{mg} / \mathrm{L}$ & 350 \\
\hline Iron & $\mathrm{mg} / \mathrm{L}$ & 0.1 \\
\hline Fluoride & $\mathrm{mg} / \mathrm{L}$ & 1.5 \\
\hline $\mathrm{pH}$ & $-\log$ & $6.5-8.0$ \\
\hline Nitrite & $\mathrm{mg} / \mathrm{L}$ & $\leq 0.1$ \\
\hline Turbidity & $\mathrm{mg} / \mathrm{L}$ & $\leq 0.0$ \\
\hline Total Hardness & $\mathrm{mg} / \mathrm{L}$ & $\leq 190$ \\
\hline Lead & $\mathrm{mg} / \mathrm{L}$ & $\leq 0.1$ \\
\hline
\end{tabular}

Source: WHO, 2012

Guidelines for Liberia Drinking Water Quality

\begin{tabular}{|c|c|c|}
\hline Parameter & Unit & $\begin{array}{c}\text { Liberia Drinking Water Quality } \\
\text { Standards (1987) }\end{array}$ \\
\hline Copper & $\mathrm{mg} / \mathrm{L}$ & $\leq 0.1$ \\
\hline Cadmium & $\mathrm{mg} / \mathrm{L}$ & 0.0001 \\
\hline Chloride & $\mathrm{mg} / \mathrm{L}$ & $\leq 250$ \\
\hline Iron & $\mathrm{mg} / \mathrm{L}$ & $\leq 0.1$ \\
\hline Fluoride & $\mathrm{mg} / \mathrm{L}$ & $\leq 1.5$ \\
\hline pH & $-\log$ & $6.5-8.0$ \\
\hline Nitrite & $\mathrm{mg} / \mathrm{L}$ & $\leq 0.1$ \\
\hline Turbidity & $\mathrm{mg} / \mathrm{L}$ & 0.0 \\
\hline Total Hardness & $\mathrm{mg} / \mathrm{L}$ & $\leq 190$ \\
\hline Lead & $\mathrm{mg} / \mathrm{L}$ & $\leq 0.1$ \\
\hline
\end{tabular}

Source: $\mathrm{MoH}, 1987$

Pollution of 32 Rivers in Thailand (Ministry of Public Health, Thailand, 1996)

\begin{tabular}{|c|c|}
\hline Types of Pollution & Number of Rivers Affected out of 32 Monitored \\
\hline Organic Waste & 13 \\
\hline Microbial Waste & 20 \\
\hline Heavy Metals & 8 \\
\hline
\end{tabular}

Source: FAO (1996), Cited in (Gogra 2002) 